\title{
ポリアミドおよびポリエステルの オリゴマーについて
}

\section{I. は がき}

高分子物質の“オリゴマー・导なわち寡量体はそれ ぞれ純粋に分離することができ，ポリマーの生成機構の 解明に市たってかなり有力な手がかりとなる。ここでは ポリアミドとしてポリカプラミド（ナイロン 6) 扎よび ポリへキサメチレンアジパミド（ナイロン 66), ポリエ ステルとしてポリエチレンテレフタレート(テトロン)を 取り上げて，その研究を展望する。これらのポリアミド およびポリエステルの分子量分布は一般に Flory 分布 に従い，基本構造単位が数個つながった鎖状をたは環状 のオリゴマーが少量存在する。

\section{II. ポリアミドのオリゴマー}

とーカプロラクタムの環状ダイマー [I] は重合尔に付着

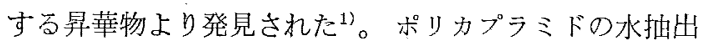
物中にも存在する2),3)。ナイロン 66 中にも少量の㻴状 ヘキサメチレンアジパミド [II] およびそのダイマーが 存在することがかなり古くより知られている ${ }^{4), 5)}$ 。

$$
\mathrm{OC}\left(\mathrm{CH}_{2}\right)_{5} \mathrm{NH}
$$

[I]
$\mathrm{OC}\left(\mathrm{CH}_{2}\right)_{4} \mathrm{CO}$
$\mathrm{HN}\left(\mathrm{CH}_{2}\right)_{6} \mathrm{NH}$

[II]
とーカプロラクタムの重合には環, 鎖状分子間に平衡が あり, 平衡時ポリマー中には約 $10 \%$ の水溶性成分が含ま れている。重合平衡時の ポリマー中の水に可溶な 環状モノマーおよびオリ ゴマーの量は第 1 表に示 すように温度が高くなる ほど多く，また環状オリ ヨ゙マーは全水溶性成分の 約 $1 / 4$ である ${ }^{6)}$ 。環状才 リゴマーは $70 \%$ ピリジ ン水溶液を展開液に用い てペーパークロマトグラ フにより分離された7?,8)。 環状および鎖状オりゴ
福本修* 緒打直哉林

第 1 表 重合平衡時のポリカプラミド中の 環状モノマーおよびオリゴマーの量

\begin{tabular}{c|c|c}
\hline \hline 重合温度 $\left({ }^{\circ} \mathrm{C}\right)$ & ラクタム & \\
\hline 230 & 6.2 & 乑状オリゴマー $(\%)$ \\
257 & 7.0 & 2.0 \\
280 & 8.3 & 2.2 \\
295 & 8.9 & 2.3 \\
310 & 10.6 & 2.4 \\
\end{tabular}

マーの量は鎖状分子と水との閒の縮合平衡を考慮すれば 当然予想されるのであるが，又応系中の水分量が増加す ると増大する ${ }^{911}$ 。オリゴマーは次式に示すような平 衡反応9) および鎖状体の“Einrollung” 反応により生 成す等 ${ }^{12)}$ と考皇られてる。

$$
\begin{gathered}
\mathrm{H}\left[\mathrm{HN}\left(\mathrm{CH}_{2}\right)_{5} \mathrm{CO}\right]_{n} \mathrm{OH} \rightleftarrows \mathrm{H}_{2} \mathrm{O}+-\left[\mathrm{HN}\left(\mathrm{CH}_{2}\right)_{5} \mathrm{CO}\right]_{n} \\
-\mathrm{CO}\left(\mathrm{CH}_{2}\right)_{5} \mathrm{NH}-\mathrm{CO}\left(\mathrm{CH}_{2}\right)_{5} \mathrm{NH}-\mathrm{CO}\left(\mathrm{CH}_{2}\right)_{5} \mathrm{NH}_{2} \\
\rightleftarrows-\mathrm{CO}\left(\mathrm{CH}_{2}\right)_{5} \mathrm{NH}_{2}+\underset{\mathrm{OC}\left(\mathrm{CH}_{2}\right)_{5} \mathrm{NH}}{\mathrm{HN}\left(\mathrm{CH}_{2}\right)_{5} \mathrm{CO}}
\end{gathered}
$$

各オリゴマーの割合についてはいろいろ測定されてい るが(13),14), Heikens ${ }^{15)}$ は真空昇華法により測定して $221.5^{\circ}$ および $253.7^{\circ} \mathrm{C}$ ではダイマー/トリマー/テトラ

\begin{tabular}{|c|c|c|c|c|c|c|}
\hline モ & オリ & マーの種類 & 融点 $\left({ }^{\circ} \mathrm{C}\right)$ & $\begin{array}{l}\text { 水に対す } \\
\text { る溶解度 } \\
(\mathrm{g} / 100 \mathrm{cc})\end{array}$ & $\begin{array}{l}\text { 加水分解速度 } \\
\text { 定数 }\left(\min ^{-1}\right)(3 N \\
\left.\mathrm{H}_{2} \mathrm{SO}_{4} 100^{\circ} \mathrm{C}\right)\end{array}$ & 文献 \\
\hline \multirow[b]{2}{*}{ とーカプロラクタム } & 環状 & $\begin{array}{l}\text { ダイマー } \\
ト リ マ ー \\
\text { テトラマー }\end{array}$ & $\begin{array}{l}343 \sim 345 \\
231 \sim 237 \\
234 \sim 236\end{array}$ & $\begin{array}{l}0.1\left(25^{\circ} \mathrm{C}\right) \\
0.93\left(25^{\circ} \mathrm{C}\right) \\
0.04\left(25^{\circ} \mathrm{C}\right)\end{array}$ & $\begin{array}{r}0.25 \times 10^{-3} \\
1.15 \times 10^{-3} \\
13.75 \times 10^{-3}\end{array}$ & 23 \\
\hline & 鎖状 & $\begin{array}{l}\text { ダィマー } \\
\text { トリマー } \\
\text { テトラマー } \\
\text { ペンタマー }\end{array}$ & $\begin{array}{l}197 \sim 198 \\
206 \sim 207 \\
207 \sim 208 \\
206 \sim 208\end{array}$ & $\begin{array}{c}- \\
1.8\left(17^{\circ} \mathrm{C}\right) \\
0.3\left(17^{\circ} \mathrm{C}\right) \\
0.01\left(17^{\circ} \mathrm{C}\right)\end{array}$ & $\begin{array}{l}- \\
- \\
- \\
-\end{array}$ & 24 \\
\hline $\begin{array}{l}\text { ヘキサメチンンジアン } \\
\text { モニウムアジペート }\end{array}$ & 環状 & $\begin{array}{l}モ ノ マ ー \\
\text { ダイマー }\end{array}$ & $\begin{array}{c}249 \sim 251 \\
237\end{array}$ & $2.35\left(25^{\circ} \mathrm{C}\right)$ & - & $\begin{array}{r}4 \\
25\end{array}$ \\
\hline
\end{tabular}
マーの比はそれぞれ 2/1/2 执よび 5/2/7 であり，ダイマ ーとテトラマーの割合が多いのは分子内水素結合をつく 第 2 表 ポリアミドのオリゴマーの性質 
り安定化しやすいためであると 説明している。しかし筆者の測 定では,この比は $1 / 1 / 1$ である。 環状ダイマーには 2 種の異性体

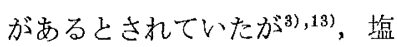
酸による部分加水分解物につい てのペーパークロマトグラフの 結果より $\alpha-$ 扝よび $\beta$ ダイマ 一はそれぞれ環状ダイマーおよ びトリマーであることが確かめられた ${ }^{16)}$ 。

ポリカプラミド中の鎖状オリゴマーはペーパークロマ トグラフ ${ }^{17)}$ (19) またはイオン交換樹脂 ${ }^{10), 20}$ により分離さ れ, Hermans らはにーアミノカプロン酸を定量して Flory の式からの計算值に一致すると報告しているが21)，筆者 らは鎖状オリゴマーの分布は Flory 分布に従わないこ とを確かめ ${ }^{11)}$ ，鎖状オリゴマーは分子鎖が大きくなるに つれて ヒーカプロラクタムとの反応速度が大きくなり，官 能基の反応性はオリヨ゙マーでは Flory の仮定したよう

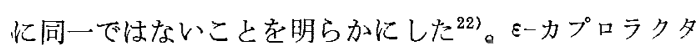
ム拉よび 66 ナイロン塩の環状および鎖状オリゴマーの 諸性質は第 2 表に示す。

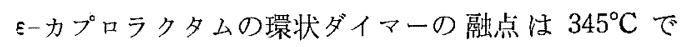
あるのに対し，この異性体である環状へキサメチレンア ジパミドの融点は $251^{\circ} \mathrm{C}$ であり, 分子の対称性がよい ため高融点であると思われる。カプロラクタムの環状 ダイマーは扣水分解反応に 対して安定であり ${ }^{25)}$, 無水の 状態では長時間 $200^{\circ} \mathrm{C}$ 以上に加熱しても変化しないが, 水の存在下では重合して た場合と同一のポリマーを与える ${ }^{2), 26)}$, 無水状態でも $\varepsilon-$ カプロラクタムとは徐々に反応してポリマーとなり ${ }^{27)}$ また解重合してをーカプロラクタムとなる2)。環状オリゴ マーは環が大きくなるにつれて加水分解速度または カプロラクタムに対する反応性が大きくなる27)。Hermans らは, 環状ダイマーは強く分子内水素結合してい るため安定であるが，環が大きくなるにつれて分子内水 素結合の力が弱くなるため反応性が大きくなると説明し ている25)。

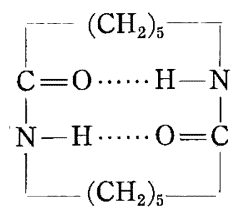

モーカプロラクタムのアミド基は共鳴のため平面形をと り水素执よび酸素原子はシス配置であるが28), ダイマー 以上の環状オリゴマーのアミドは赤外吸収スペクトルの 結果ではトランス配置である ${ }^{29)}$ 。

E-アミノカプロン酸の鎖状オリゴマーは van der Want らにより次式に示すような経路で合成された ${ }^{30)}$ 。 
ポリエチレンテレフタレートではひずみのため環状ダ イマーはできないが35)，ポリェチレンイソフタレートか ら注融点 $325 \sim 327^{\circ} \mathrm{C}$ の環状ダイマー [IV] がポリマー の $10 \sim 15 \%$ 得られる ${ }^{36)}$ 。

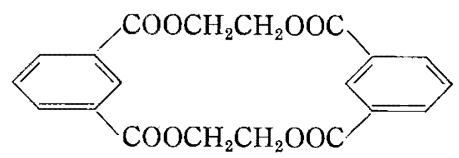

[IV]

Zahn らは末端がジオール, ジカルボン酸, ジェステ ルおよびオキシ酸の各種のポリエチレンテレフタレート のオリゴマーを合成してその融点, 赤外吸収スペクトル およびX 線スペクトルを測定し, ジオール型のオリゴマ 一の融点と鎖長の閒には次式に示すよらな関係がなりた つことを見出している ${ }^{8)}$ 。

$$
\begin{aligned}
& 1 / T_{f}=a+b / Z \\
& T_{f}: \text { 融点 } Z: \quad \text { 鎖中の原子数 } \\
& a=1.783 \times 10^{-3} \quad b=11.58 \times 10^{-3}
\end{aligned}
$$

三宅は各種のオリゴマーを合成してその赤外吸収スぺ クトルを測定し，これよりポリェチレンテレフタレート の吸収の帰属を行なった ${ }^{37)}$ 。オリゴマーは次のようにし て合成される ${ }^{8), 37)}$ 。
6) 由本: Bull. Chem. Soc. Japan, 28, 94(1955)

7) H. Zahn and E. Rexroth: Z. anal. Chem., 148, 181 (1955)

8) H. Zahn, et al: Angew. Chem., 68, 229 (1956)

9) F. Wiloth: Zeit. phys. Chem., 5, 66(1955)

10) P. H. Hermans: J. Appl. Chem., 5, 493 (1955)

11) 由本, 緒方： Makromol. Chem., 25, 91(1958)

12) A. Matthes: ibid., 5, $197(1950)$

13) 福本: Bull. Chem. Soc. Japan, 29, 169 (1956)

14) I. Rothe and M. Rothe : Chem. Ber., 88, 284(1955)

15) D. Heikens : R c. trav. chim., 75, 1199(1956)

16) P. H. Hermans: Nature, 177, 126(1956)

17) H. Zahn and H. Wolf : Melliand Textilber., 32, 317 (1951)

18) H. Zahn and B. Wollemann : itid., 32, 927 (1951)

19) D. Heikens : P. H. Hermans and P. F. van Welden: Nature, 174, 1187 (1954)

20) C. W. Ayers and S. Smith: Chem. Ind., 11, 684 (1955)

21) P. H. Hermans, D. Heikens and P. F. van Welden: J. Polym. Sci., 16, 451 (1955)

22) 由本, 緒方: Makromol. Chem., 25, 71 (1958)

23）緒方：未発表

24) G. M. van der Want, H. Peters and P. Inklaar : Rec. trav. chim., 71, 1221 (1952)
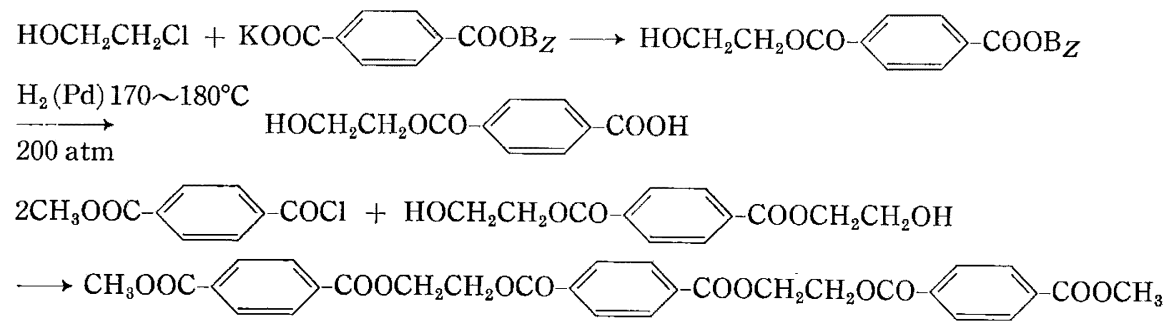

オリジマーを高沸点の溶媒に溶解して加熱すれば縮合 がおこるので適当な反応条件を選べば希望する重合度の オリゴマーが得られる。

\section{IV. むす}

ポリアミドおよびポリエステルのオリゴマーのうち, 特に 衡の問題に関連して詳細に研究されているが，オリゴマ 一の反応性はモノマーまたはポリマーとは違った挙動を 示し，今後の解明にまつところが大きい。(* 東洋レー ヨン(株) 名古屋工場 - ** 同社研究部名古屋研究室)

$$
\text { 文献 }
$$

1) 星野: Bull. Chem. Soc. Japan, 19, 171 (1944)

2) P. B., 44806(1944)

3) P. H. Hermans: Rec. trav, chim., 72, 798(1953)

4) C. H. Greenwalt: U.S., 2,241,323(1938)

5) C. J. Brown, A. Hill and P. V. Youle: Nature, $177,128(1956)$
25) P. H. Hermans: Nature, 177, $127(1956)$

26) M. Rothe: J. Polym. Sci., 30, 227 (1958)

27) 緒方：昭和 33 年秋季研究発表大会講演要旨集, 68 ページ

29) 坪井：Bull. Chem.Soc. Japan, 22, 215(1949)

29）向山, 緒方: 未発表

30) G. M. van der Want and A. J. Staveman: Rec. trav. chim., 71, .379(1952)

31) H. West: Faserforsch. u. Texiltech.,5, 145(1954)

32) H. Zahn and W Layer : Makromol. Chem., 23, 85(1957)

33) H. Zahn and H. Determann: Chem. Ber., 90, $2176(1957)$

34) M. Rothe and F. W. Kunitz: Angew. Chem., 68, 414-(1956):

35) S. D. Ross, et al : J. Polym. Sci., 13, 406(1954)

36) J. D. Burnett, R. G. J. Miller and H.A. Willis : ibid., 15, 591(1955)

37) 三宅：第 5 回赤外ラマンスペクトル討論会 (昭 33 年 10 月) 